Editor's Note: These short reviews of recent JNeurosci articles, written exclusively by students or postdoctoral fellows, summarize the important findings of the paper and provide additional insight and commentary. If the authors of the highlighted article have written a response to the Journal Club, the response can be found by viewing the Journal Club at www.jneurosci.org. For more information on the format, review process, and purpose of Journal Club articles, please see http://jneurosci.org/content/ preparing-manuscript\#journalclub.

\title{
Cognitive Control, the Anterior Cingulate, and Nicotinic Receptors: A Case of Heterozygote Advantage
}

\author{
이 Jason Smucny \\ Department of Psychiatry and Behavioral Sciences, University of California, Davis, Sacramento, California 95817 \\ Review of Sadaghiani et al.
}

The cholinergic neurotransmitter system, via diffuse projections emanating from the basal forebrain and synapsing onto numerous cortical targets, modulates several neurocognitive functions, including attention, working memory, and cognitive control (Picciotto et al., 2012). Concordantly, loss-of-function in this system is associated with cognitive impairment in numerous psychiatric and neurological disorders such as Alzheimer's disease (Francis et al., 1999), epilepsy (Ghasemi and Hadipour-Niktarash, 2015), and schizophrenia (Sarter et al., 2012; Smucny and Tregellas, 2013), making it an attractive target for therapeutic intervention.

The most abundantly expressed cholinergic receptor in the mammalian brain is the ionotropic nicotinic $\alpha_{4} \beta_{2}$ receptor. Interestingly, behavioral phenotypes may be modulated at the level of single-nucleotide polymorphisms (SNPs) of $\alpha_{4} \beta_{2}$ receptor-encoding genes. A striking example of this phenomenon is demonstrated by the rs1044396 SNP of the $\alpha_{4}$ subunit encoding gene CHRNA4, which influences neurocognitive processes such

Received Sept. 26, 2017; revised Nov. 6, 2017; accepted Nov. 9, 2017.

This work was supported in part by a fellowship from the National Institutes of Mental Health (F32 MH114325-01).

The author declares no competing financial interests.

Correspondence should be addressed to Dr. Jason Smucny, Imaging

Research Center, University of California, Davis, 4701 X Street, Sacramento, CA 95817. E-mail: jsmucny@ucdavis.edu.

DOI:10.1523/JNEUROSCI.2775-17.2017

Copyright $\odot 2018$ the authors $\quad 0270-6474 / 18 / 380257-03 \$ 15.00 / 0$ as attention (Parasuraman et al., 2005; Reinvang et al., 2009; Espeseth et al., 2010) as well as nicotine addiction (Breitling et al., 2009; Rocha Santos et al., 2015). The relationships between its allelic combinations (T/T, T/C, and C/C) and cognition, however, are unclear. Some studies have demonstrated an advantage (e.g., increased attentional load capacity) with the $T$ allele (Greenwood et al., 2005, 2012; Espeseth et al., 2010) and others an advantage (e.g., decreased reaction times) with the $\mathrm{C}$ allele (Parasuraman et al., 2005; Reinvang et al., 2009). Heterozygotes, furthermore, have not been well characterized.

To clarify the effects of these alleles, Sadaghiani et al. (2017) recently examined functional activation (using fMRI) and performance during cognitive controlassociated tasks in healthy young adults with the T/T, T/C, or C/C rs1044396 genotype. The authors focused on activation of the cingulo-opercular network because of its demonstrated importance in cognitive control-associated functions (Lesh et al., 2011; Sheffield et al., 2015) and robust nicotinic receptor expression (Paterson and Nordberg, 2000).

To maximize statistical power, Sadaghiani et al. (2017) used large datasets from two publicly available databases: the IMAGEN dataset (Schumann et al., 2010; $\left.n_{\mathrm{fMRI}}=1358\right)$ and the Philadelphia Neurodevelopmental Cohort (PNC; Satterthwaite et al., 2014; $n_{\mathrm{fMRI}}=228$ ). For the IMAGEN dataset, brain network activity was analyzed during a Stop-Signal task. In this task, subjects were asked to respond to left or right-pointing arrows with a left or right button press (respectively), but were told to withhold the response when the arrow was followed by a "stop" signal (up arrow). Cognitive control-associated activity was defined as brain activity during all "stop" trials and during errors on "go" trials. Activity during "stop" trials measures the response inhibition aspect of control, and activity during errors-only "go" trials measures the response conflictdriven, task adjustment aspect of control (Verbruggen and Logan, 2008). For the PNC dataset, network activity was analyzed during a visual $n$-back working memory task. For this task, subjects were asked to determine whether an abstract geometric image matched a target image (0-back condition), the image shown previously (1-back condition), or the image shown two trials previously (2-back condition). Cognitive control-associated activity was defined as brain activity across all conditions.

Under this framework, Sadaghiani et al. (2017) found that heterozygotes (T/C subjects) showed greater task-associated activity in the cingulo-opercular network than either $\mathrm{T} / \mathrm{T}$ or $\mathrm{C} / \mathrm{C}$ homozygotes. This effect was specific to the cingulo-opercular network: group differences were not observed in the default, dorsal attention, or frontoparietal networks. Heterozygotes also showed greater accuracy during other visual continuous performance tasks relative 
to homozygotes. These results suggest that heterozygotes show both increased activation of neuronal circuits during cognitive control-related tasks as well as improved overall performance relative to either homozygous genotype.

To further understand the mechanism underlying this difference, Sadaghiani et al. (2017) analyzed gene expression data from the Genotype-Tissue expression project database (GTEx Consortium, 2015). They found that $\mathrm{T} / \mathrm{T}$ homozygotes had the greatest CHRNA4 expression levels, with $\mathrm{T} / \mathrm{C}$ heterozygotes showing intermediate levels and $\mathrm{C} / \mathrm{C}$ homozygotes the lowest levels. This finding suggests that the rs1044396 SNP may affect cognition by affecting $\alpha_{4}$ subunit expression.

These results have important implications for our understanding of the relationships between receptor expression and neurotransmitter signaling by suggesting that intermediate expression of the CHRNA4 gene may confer an optimal level of nicotinic signaling for cognitive control. Why might such an "inverted U" shaped effect occur? One possibility may lie in how the nicotinic system influences the balance between excitation and inhibition (i.e., E/I balance) in the brain. Healthy brain function depends upon homeostatic control of cortical excitability allowing for dynamic control of plasticity and information transfer to optimize efficiency according to task demands (Krause et al., 2013). Over-inhibition may prevent the appropriate neural circuits from being activated, whereas prolonged hyperexcitation may induce neurotoxicity (Krause et al., 2013). Improper E/I balance may also reduce the dynamic range over which neuronal circuits may be perturbed, inducing floor or ceiling effects preventing performance optimization. Given that one of the primary functions of the nicotinic $\alpha_{4} \beta_{2}$ receptor is to enable ion influx and neuronal depolarization, it follows that rs1044396 T/C heterozygotes (which show intermediate levels of receptor expression) may have improved E/I balance relative to either homozygous genotype. Indeed, previous studies have shown that knock-out of the lynxl gene, which acts as a "brake" on nicotinic receptor signaling, not only enhances receptor activation but also induces vacuolation and neurodegeneration (Miwa et al., 2006). Differences in basal nicotinic signaling may also affect E/I balance by inducing downstream alterations in glutamatergic (Mansvelder et al., 2002) and GABAergic (Maloku et al., 2011) signaling. Interestingly, it is possible that the inverted U-shaped dose-response curves observed in other neurotransmitter systems, such as dopamine (Cools and D'Esposito, 2011) and serotonin (Cano-Colino et al., 2014), are also due to the influence of these systems on E/I balance.

Regardless of the mechanism, the results of Sadaghiani et al. (2017) have important implications for the understanding and treatment of diseases with nicotinic associations. Schizophrenia, for example, is associated with high rates of nicotine dependence that have been hypothesized to be a form of self-medication to normalize deficient levels of nicotinic signaling (Winterer, 2010). Supporting this view, previous neuroimaging studies have observed reduced expression of nicotinic receptors in schizophrenia (Freedman et al., 1995; D'Souza et al., 2012). Tying this result to the Sadaghiani et al. (2017) paper, schizophrenia patients also show behavioral and functional deficits in cognitive control (including reduced anterior cingulate activation; Lesh et al., 2011, 2013; Culbreth et al., 2016; Smucny et al., 2017). Although no known relationship exists between risk for schizophrenia and the rs1044396 SNP, it is possible that the rs1044396 SNP may influence endophenotypic traits associated with the illness, e.g., deficits in cognitive control. Indeed, it has been suggested that the effects of single gene mutations may be better isolated in polygenic disorders such as schizophrenia on an endophenotypic level (as demonstrated by the nicotinic $\alpha 7$ receptor-encoding the $C H R N A 7$ gene and impaired P50 gating; Leonard et al., 2002; Sinkus et al., 2015) due to the fact that large numbers of genes influence schizophrenia risk (Leonard et al., 2002). In regard to treatment, although the nicotinic receptor has received considerable attention as a potential drug target for schizophrenia (Freedman, 2014; Featherstone and Siegel, 2015), results from these trials have thus far been mixed. Several trials have failed, and no drug is yet FDA approved to treat any symptom (Freedman et al., 2008; Shim et al., 2012; Velligan et al., 2012; Walling et al., 2016; Kem et al., 2017). One possible explanation for the slow progress of these drugs is genetic heterogeneity. Some patients, for example, may have SNPs in CHRNA4 and other nicotinic receptor genes that affect receptor affinity and expression (Greenwood et al., 2012). Different drug doses might consequently be required to elicit maximum benefit depending on haplotype, and comparison of nicotinic drug effects between rs1044396 (and other) alleles could help optimize doses. Related to this point, a previous neuroimaging study using an $\alpha_{7}$ nicotinic receptor partial agonist found differential effects depending on CHRNA7 (the $\alpha_{7}$ nicotinic receptor gene) genotype (Tregellas et al., 2011).

By demonstrating heterozygote advantage in human nicotinic receptor SNPs, the work by Sadaghiani et al. (2017) makes an important contribution to our understanding of how genes can shape the neuronal mechanisms of cognition. This study is also one of the first neuroimaging genetics studies to take advantage of large public databases. To this point, reproducibility has been an issue in neuroimaging genetics studies due to low power associated with small sample sizes (Carter et al., 2017). This challenge has been difficult to overcome because of the high costs (\$500-1000 per MRI scan; Paulus and Stein, 2007) and long study durations necessary to conduct large-scale functional imaging studies. Publicly available databases such as IMAGEN and the PNC will help overcome this hurdle by freely enabling neuroscience researchers to analyze data collected in parallel across numerous sites, exponentially increasing overall efficiency and reproducibility in the search for genetic mechanisms that underlie dysfunctional neurocognitive processes in neurological and psychiatric disease.

\section{References}

Breitling LP, Dahmen N, Mittelstrass K, Rujescu D, Gallinat J, Fehr C, Giegling I, Lamina C, Illig T, Müller H, Raum E, Rothenbacher D, Wichmann HE, Brenner H, Winterer G (2009) Association of nicotinic acetylcholine receptor subunit alpha 4 polymorphisms with nicotine dependence in 5500 Germans. Pharmacogenomics J 9:219-224. CrossRef Medline

Cano-Colino M, Almeida R, Gomez-Cabrero D, Artigas F, Compte A (2014) Serotonin regulates performance nonmonotonically in a spatial working memory network. Cereb Cortex 24:2449-2463. CrossRef Medline

Carter CS, Bearden CE, Bullmore ET, Geschwind DH, Glahn DC, Gur RE, Meyer-Lindenberg A, Weinberger DR (2017) Enhancing the informativeness and replicability of imaging genomics studies. Biol Psychiatry 82:157-164. CrossRef Medline

Cools R, D’Esposito M (2011) Inverted-U-shaped dopamine actions on human working memory and cognitive control. Biol Psychiatry 69:e113125. CrossRef Medline

Culbreth AJ, Gold JM, Cools R, Barch DM (2016) Impaired activation in cognitive control regions predicts reversal learning in schizophrenia. Schizophr Bull 42:484-493. CrossRef Medline

D'Souza DC, Esterlis I, Carbuto M, Krasenics M, Seibyl J, Bois F, Pittman B, Ranganathan M, Cosgrove K, Staley J (2012) Lower ss2*-nicotinic acetylcholine receptor availability in smokers with schizophrenia. Am J Psychiatry 169:326-334. CrossRef Medline

Espeseth T, Sneve MH, Rootwelt H, Laeng B (2010) Nicotinic receptor gene CHRNA4 in- 
teracts with processing load in attention. PLoS One 5:e14407. CrossRef Medline

Featherstone RE, Siegel SJ (2015) The role of nicotine in schizophrenia. Int Rev Neurobiol 124:23-78. CrossRef Medline

Francis PT, Palmer AM, Snape M, Wilcock GK (1999) The cholinergic hypothesis of Alzheimer's disease: a review of progress. J Neurol Neurosurg Psychiatry 66:137-147. CrossRef Medline

Freedman R (2014) $\alpha 7$-Nicotinic acetylcholine receptor agonists for cognitive enhancement in schizophrenia. Annu Rev Med 65:245-261. CrossRef Medline

Freedman R, Hall M, Adler LE, Leonard S (1995) Evidence in postmortem brain tissue for decreased numbers of hippocampal nicotinic receptors in schizophrenia. Biol Psychiatry 38: 22-33. CrossRef Medline

Freedman R, Olincy A, Buchanan RW, Harris JG, Gold JM, Johnson L, Allensworth D, GuzmanBonilla A, Clement B, Ball MP, Kutnick J, Pender V, Martin LF, Stevens KE, Wagner BD, Zerbe GO, Soti F, Kem WR (2008) Initial phase 2 trial of a nicotinic agonist in schizophrenia. Am J Psychiatry 165:1040-1047. CrossRef Medline

Ghasemi M, Hadipour-Niktarash A (2015) Pathologic role of neuronal nicotinic acetylcholine receptors in epileptic disorders: implication for pharmacological interventions. Rev Neurosci 26:199-223. CrossRef Medline

Greenwood PM, Fossella JA, Parasuraman R (2005) Specificity of the effect of a nicotinic receptor polymorphism on individual differences in visuospatial attention. J Cogn Neurosci 17:1611-1620. CrossRef Medline

Greenwood PM, Parasuraman R, Espeseth T (2012) A cognitive phenotype for a polymorphism in the nicotinic receptor gene CHRNA4. Neurosci Biobehav Rev 36:1331-1341. CrossRef Medline

Kem WR, Olincy A, Johnson L, Harris J, Wagner BD, Buchanan RW, Christians U, Freedman R (2017) Pharmacokinetic limitations on effects of an Alpha7-nicotinic receptor agonist in schizophrenia: randomized trial with an extended-release formulation. Neuropsychopharmacology. Advance online publication. Accessed November 6, 2017. doi: 10.1038/ npp.2017.182. Medline

Krause B, Márquez-Ruiz J, Cohen Kadosh R (2013) The effect of transcranial direct current stimulation: a role for cortical excitation/ inhibition balance? Front Hum Neurosci 7:602. CrossRef Medline

Leonard S, Gault J, Hopkins J, Logel J, Vianzon R, Short M, Drebing C, Berger R, Venn D, Sirota P, Zerbe G, Olincy A, Ross RG, Adler LE, Freedman R (2002) Association of promoter variants in the alpha7 nicotinic acetylcholine receptor subunit gene with an inhibitory deficit found in schizophrenia. Arch Gen Psychiatry 59:1085-1096. CrossRef Medline

Lesh TA, Niendam TA, Minzenberg MJ, Carter CS (2011) Cognitive control deficits in schizophrenia: mechanisms and meaning. Neuropsychopharmacology 36:316-338. CrossRef Medline

Lesh TA, Westphal AJ, Niendam TA, Yoon JH, Minzenberg MJ, Ragland JD, Solomon M,
Carter CS (2013) Proactive and reactive cognitive control and dorsolateral prefrontal cortex dysfunction in first episode schizophrenia. Neuroimage Clin 2:590-599. CrossRef Medline

Maloku E, Kadriu B, Zhubi A, Dong E, Pibiri F, Satta R, Guidotti A (2011) Selective alpha4beta2 nicotinic acetylcholine receptor agonists target epigenetic mechanisms in cortical GABAergic neurons. Neuropsychopharmacology 36 : 1366-1374. CrossRef Medline

Mansvelder HD, Keath JR, McGehee DS (2002) Synaptic mechanisms underlie nicotine-induced excitability of brain reward areas. Neuron 33: 905-919. CrossRef Medline

Miwa JM, Stevens TR, King SL, Caldarone BJ, Ibanez-Tallon I, Xiao C, Fitzsimonds RM, Pavlides C, Lester HA, Picciotto MR, Heintz N (2006) The prototoxin lynxl acts on nicotinic acetylcholine receptors to balance neuronal activity and survival in vivo. Neuron 51: 587-600. CrossRef Medline

Parasuraman R, Greenwood PM, Kumar R, Fossella J (2005) Beyond heritability: neurotransmitter genes differentially modulate visuospatial attention and working memory. Psychol Sci 16:200-207. CrossRef Medline

Paterson D, Nordberg A (2000) Neuronal nicotinic receptors in the human brain. Prog Neurobiol 61:75-111. CrossRef Medline

Paulus MP, Stein MB (2007) Role of functional magnetic resonance imaging in drug discovery. Neuropsychol Rev 17:179-188. CrossRef Medline

Picciotto MR, Higley MJ, Mineur YS (2012) Acetylcholine as a neuromodulator: cholinergic signaling shapes nervous system function and behavior. Neuron 76:116-129. CrossRef Medline

Reinvang I, Lundervold AJ, Rootwelt H, Wehling E, Espeseth T (2009) Individual variation in a cholinergic receptor gene modulates attention. Neurosci Lett 453:131-134. CrossRef Medline

Rocha Santos J, Tomaz PR, Issa JS, Abe TO, Krieger JE, Pereira AC, Santos PC (2015) CHRNA4 rs1044396 is associated with smoking cessation in varenicline therapy. Front Genet 6:46. CrossRef Medline

Sadaghiani S, Ng B, Altmann A, Poline JB, Banaschewski T, Bokde ALW, Bromberg U, Büchel C, Burke Quinlan E, Conrod P, Desrivières S, Flor H, Frouin V, Garavan H, Gowland P, Gallinat J, Heinz A, Ittermann B, Martinot JL, Paillère Martinot ML, et al. (2017) Overdominant effect of a CHRNA4 polymorphism on cingulo-opercular network activity and cognitive control. J Neurosci 37:9657-9666. CrossRef Medline

Sarter M, Lustig C, Taylor SF (2012) Cholinergic contributions to the cognitive symptoms of schizophrenia and the viability of cholinergic treatments. Neuropharmacology 62:1544-1553. CrossRef Medline

Satterthwaite TD, Elliott MA, Ruparel K, Loughead J, Prabhakaran K, Calkins ME, Hopson R, Jackson C, Keefe J, Riley M, Mentch FD, Sleiman P, Verma R, Davatzikos C, Hakonarson H, Gur RC, Gur RE (2014) Neuroimaging of the Philadelphia neurodevelopmental cohort. Neuroimage 86:544-553. CrossRef Medline

Schumann G, Loth E, Banaschewski T, Barbot A,
Barker G, Büchel C, Conrod PJ, Dalley JW, Flor H, Gallinat J, Garavan H, Heinz A, Itterman B, Lathrop M, Mallik C, Mann K, Martinot JL, Paus T, Poline JB, Robbins TW, et al. (2010) The IMAGEN study: reinforcementrelated behaviour in normal brain function and psychopathology. Mol Psychiatry 15: 1128-1139. CrossRef Medline

Sheffield JM, Repovs G, Harms MP, Carter CS, Gold JM, MacDonald AW 3rd, Daniel Ragland J, Silverstein SM, Godwin D, Barch DM (2015) Fronto-parietal and cingulo-opercular network integrity and cognition in health and schizophrenia. Neuropsychologia 73:82-93. CrossRef Medline

Shim JC, Jung DU, Jung SS, Seo YS, Cho DM, Lee JH, Lee SW, Kong BG, Kang JW, Oh MK, Kim SD, McMahon RP, Kelly DL (2012) Adjunctive varenicline treatment with antipsychotic medications for cognitive impairments in people with schizophrenia: a randomized double-blind placebo-controlled trial. Neuropsychopharmacology 37:660-668. CrossRef Medline

Sinkus ML, Graw S, Freedman R, Ross RG, Lester HA, Leonard S (2015) The human CHRNA7 and CHRFAM7A genes: a review of the genetics, regulation, and function. Neuropharmacology 96:274-288. CrossRef Medline

Smucny J, Tregellas J (2013) Nicotinic modulation of intrinsic brain networks in schizophrenia. Biochem Pharmacol 86:1163-1172. CrossRef Medline

Smucny J, Lesh TA, Newton K, Niendam T, Ragland JD, Carter CS (2017) Levels of cognitive control: a functional magnetic resonance imaging-based test of an $\mathrm{RDoC}$ domain across bipolar disorder and schizophrenia. Neuropsychopharmacology. Advance online publication. Accessed November 6, 2017. CrossRef Medline

GTEx Consortium (2015) Human genomics. The Genotype-Tissue Expression (GTEx) pilot analysis: multitissue gene regulation in humans. Science 348:648-660. CrossRef Medline

Tregellas JR, Tanabe J, Rojas DC, Shatti S, Olincy A, Johnson L, Martin LF, Soti F, Kem WR, Leonard S, Freedman R (2011) Effects of an alpha 7-nicotinic agonist on default network activity in schizophrenia. Biol Psychiatry 69: 7-11. CrossRef Medline

Velligan D, Brenner R, Sicuro F, Walling D, Riesenberg R, Sfera A, Merideth C, Sweitzer D, Jaeger J (2012) Assessment of the effects of AZD3480 on cognitive function in patients with schizophrenia. Schizophr Res 134:5964. CrossRef Medline

Verbruggen F, Logan GD (2008) Response inhibition in the stop-signal paradigm. Trends Cogn Sci 12:418-424. CrossRef Medline

Walling D, Marder SR, Kane J, Fleischhacker WW, Keefe RS, Hosford DA, Dvergsten C, Segreti AC, Beaver JS, Toler SM, Jett JE, Dunbar GC (2016) Phase 2 trial of an alpha-7 nicotinic receptor agonist (TC-5619) in negative and cognitive symptoms of schizophrenia. Schizophr Bull 42:335-343. CrossRef Medline

Winterer G (2010) Why do patients with schizophrenia smoke? Curr Opin Psychiatry 23:112119. CrossRef Medline 